\title{
MINU EESTI LUULE TÕLKESPETSIIFIKA
}

\author{
GUNTARS GODIN̦
}

$\mathrm{E}$ esti keelt hakkasin õppima täiesti juhuslikult. Mulle meeldis eesti keele musikaalsus, kuid kuskil alateadvuses oli mul juba plaangi valmis tahtsin tõlkima hakata. Enne seda olin ette võtnud indoneesia keele, kuid mul polnud sellele konkreetseid rakendusvõimalusi, ja polnud ka kedagi, kellega oleks olnud võimalik selles keeles rääkida. Kirjutasin oma Tallinnas ilmunud eestikeelse luulekogumiku „Öö päike” eessõnas: „Ei teagi, miks mul aastaid tagasi väikeses Läti linnas Viesītes tekkis huvi eesti keele ja kirjanduse vastu. Seal meenutab see rohkem eksootilist unenägu, midagi väga-väga kauget ja mõeldamatut." (Godiņš 2000: 5) Võin vaid tõdeda, et tolles väikeses linnakeses mõjusid nii indoneesia kui ka eesti keel ühevõrra eksootiliselt.

Minu esimesed luuletused ilmusid möödunud sajandi kaheksakümnendate aastate alguses, 1985. aastal avaldati mu esimene luulekogu (Godin̄š 1985), kust tsensor oli pooled luuletused välja rookinud. Pärast seda ei saanud ma paari aasta jooksul Lätis omaenda luuletusi avaldada, kuid olin just parajasti hakanud tõlkima eesti luulet ja - eesti luulet võis juba avaldada. Jaan Kaplinski oli esimene eesti luuletaja, kelle luulet ma tõlkida võtsin. Oma esimestel Eesti-sõitudel ostsin endale Kaplinski luuleraamatud ja hakkasingi tõlkima.

Nüüdseks on mu tõlkes ilmunud luulet, proosat, lasteraamatuid, näidendeid jne. Tõlgitud autorite seas on Jaan Kaplinski, Hando Runnel, Artur Alliksaar, Ilmar Laaban, Paul-Eerik Rummo, Doris Kareva, Tõnu Õnnepalu, Mats Traat, Ene Mihkelson, Jaak Jõerüüt, Andrus Kivirähk, (:)kivisildnik, Contra jt.

\section{Rahvaluuletekstide tõlkimine}

Olen juba mitu aastat tegelenud nii soome kui ka eesti rahvaluule tõlkimisega. Minu esimene tõlkeraamat ilmus 1993. aastal - see oli soome kangelaslugude, ballaadide ja legendide kogumik „Kanteletar” (Godiņš 1993). Juba tollal uurisin väga põhjalikult soome-ugri mütoloogiat ja poeetikat. Hiljem võtsin käsile eesti rahvaluule tõlkimise. 2002. aastal ilmus mu tõlkes eesti rahvaluulevalimik „Ozols auga debesīs” (e k „Tamm kasvas taeva'esse”), mis pälvis Läti kirjanduse aastapreemia.

Eesti rahvaluule poeetika on olnud mu aastatepikkune uurimisteema ja selle tulemusena olen välja töötanud tõlkepõhimõtted soome-ugri rahvaluule lätindamiseks. Üheks olulisemaks nüansiks on seejuures keele musikaalsus: sage assonantside, alliteratsiooni, epifooride, korduste kasutamine.

Kirjandusteadlased on püstitanud hüpoteesi, et regivärss on välja kujunenud balti hõimude mõjul, ajal, kui soome-ugri ja balti hõimud elasid kõrvuti. Kuigi eesti ja soome rahvalaulu värsirida koosneb üldjuhul neljast trohheili- 
sest värsijalast (kaheksast silbist), on siiski tegemist komplitseerituma ilminguga, sest tuginetakse kvantiteerivale (vältelisele) värsivormile, silpide arvule (süllaabiline põhimõte), rõhkude arvule ja kordustele (tooniline põhimõte). Eesti värsimeetrika uurija Jaak Põldmäe (1978) on ilmingut nimetanud kvantiteeriv-süllabotooniliseks põhimõtteks. Eesti rahvalaulu (regivärsi) meetrikavariandid jagunevad sümmeetrilise (korrapärase) rütmiga värssideks $(4+4$; $2+4+2 ; 2+2+4 ; 4+2+2$ silbiga sõnade ühendus) ja assümmeetrilise rütmiga (murtud) värssideks $(2+3+3 ; 3+2+3 ; 3+3+2)$. (Põldmäe 1978: 151-157)

Eesti rahvalaulu keel erineb eesti kirjakeelest juba seetõttu, et nende ajalooline kujunemine pole ühtinud. Regilaulu keeles esinevad morfoloogilised erandid tekkisid peaasjalikult kõlalisuse ja rütmilisuse pärast, samuti dialektoloogiliste iseärasuste tõttu. Nimetatud erandeid on põhjalikult käsitlenud eesti rahvaluuleteadlane Eduard Laugaste (1977), Juhan Peegel (1982-1989) on koostanud sõnastiku „Nimisõnade poeetilised sünonüümid eesti regivärssides".

Eesti rahvalaulu erilise kõlalisuse üks põhjuseid on rahvalaulude suhteliselt tagasihoidlik muusikaline materjal. Eesti rahvalaulude esitus, erinevalt läti rahvamuusikast, meenutab rohkem skandeerimist, retsiteerimist, mitte laulmist. Sestap võib öelda, et muusikaline materjal loob omalaadse rütmilise raamistiku, teksti kohandatakse meloodia ladusa voo nimel, seejuures muudetakse meetrilisi aktsente (need erinevad omakorda sõnas olevatest loogilistest rõhkudest).

Suhteliselt kasinast muusikalisest materjalist tingituna on kujunenud värvirikas sõnakõla, mida iseloomustavad mitmesugused kordused: $\mathrm{p}$ a r alle lis m (sünonüümne, analoogiline, nende kombinatsioon), ster e o tü üpsus (öeldut korratakse ilma mõtteliste muutusteta või minimaalsete mõtteliste muutustega: Kui mina hakkan laulamaie, / laulamaie, luulemaie), s õ n a d e, värsiridade kordus (Paras, paras, peremeesi, / lina ütleb: liigu, liigu). (Laugaste 1977: 151-164)

Läti rahvaluuleski leiame algriime, kuigi vähem kui eesti rahvaluules. Nt Riti, riti, rīta rasa ('Kõnni, kõnni, koidu kaste') või Gludu, gludu galvu glaudu ('Siledat, siledat silepead silitan').

Eesti ja soome rahvalaule on läti keelde tõlgitud ainult neljajalgse trohheuse abil. Samas on läti rahvalaulu värss valdavalt kaheksasilbiline, tema rütm trohheiline, kuid mitte päris trohheus, pigem võiks rääkida trohheilisest tendentsist. Muidugi, oma rolli mängib ka eesti ja läti rahvaluule struktuur. Läti rahvalaulud koosnevad põhimõtteliselt neljast reast, eesti rahvalaulud on pikemad.

Eesti vanade rahvalaulude tõlkimisel olen püüdnud tabada nii keele musikaalsust kui ka rütmilist struktuuri.

\section{Loomine}

Üks on õunapuu mäella, üks on oksa õunapuussa, üks on õile oksa päällä, üks on õuna õile päällä.

\section{Radī̌̌ana}

Viena ābele stāv kalnā, ābele ar vienu zaru, zied viens zieds uz garā zara, aug viens ābols no tā zieda. 
Sie õuna mõnesugune:

kuu puolt kumerikene, päävä puolt on punasikene, Riia puolt on ristiline, Narva puolt on naastuline. Harju puolt on aukuline.

Tuli üksi suuri tuuli, sai üksi sadune ilma, vieretas õuna vedeje, ajas õuna allikaie.

Mis sest ounast sündinekse?

Sinikirja linnukene, sinikirja, siibakirja. Luogelekse linnukene, luogelekse, lendelekse, lendas meie lepikuie, kukkus meie koppelie, arvas meie haavikuie, määras meie männikuie.

Meie koplis kolme põesast: üks oli sinine põesas, teine on punane põesas, kolmas kullakarvaline.

Sinikirja linnukene, ära puoe sinise põesa, ära puoe punase põesa, puoe kullakarvasesse!

Võttas kuldase omaksi, hõbedaise arma'aksi.

Sinisiiba linnuke hakkas siis pesa tegema.

Sai siis pesa valmi'eksi, hakkas siis mune munema. Sai siis munad munetud, hakkas poegi haudumaie.

Said pojad verisulije, hakkas puoegi pillutama: ühe pani kuuks Kuuramaale, teised pani täheks taeva'aie, kolmas päevaks pääle ilma.

(Eesti rahvalaulud I: 13)
Ābols tas tik daudzu veidu: mēness pusē apalītis, saules pusē sarkanītis, Rīgas pusē krustanītis, Narvas pusē plakanītis. Harju pusē caurumītis.

Nāca virsū lieli vēji, nesa līdzi lietus laiku, ābols ripoja ūdenī, ābols iekrita avotā.

Kas no ābolīša dzima?

Zilspārnītis, mazspārnītis, zilspārnītis, zīdspārnītis. Lokus meta mazais putniņš, lokus meta, laidelējās, alsknājā tas ielaidās, aplokā tas nolaidās, apsājā tas pasēdēja, priedājā tas palika.

Mūsu aplokā trīs krūmi: vienam krūmam zilas lapas, otram sarkanas ir lapas, trešam krūmam zelta lapas.

Zilspārnīti, mazspārnīti, nesēdies tu zilā krūmā, nesēdies tu sarkanā, sēdies zelta krāsas krūmā!

Sēdās putniṇš zelta krūmā, sudrabiṇa krūmā sēdās.

Zilspārnītis, mazspārnītis ligzdu vija zelta krūmā.

Ligzda gatava kad tika, olas dēja zelta krūmā. Olas izdētas kad tika, perēt bērnus sēdās putniņš.

Tad, kad spalva bērniem tika, sāka bērnus izmētāt: viens lai mēness Kurzemē, otrs zvaigzne debesjumā, trešais saule pasaulē.

(Godin̄š 2002: 15-16)

Keele musikaalsus on suurel määral tingitud sagedasest algriimide kasutamisest (alliteratsioon ja assonants). Mitmed eesti ja soome teadlased on nimetatud nähtust põhjendanud vajadusega pidada meeles pikki tekstimassiive. Läti rahvalauludes on alliteratsioon ja assonants juhuslik, mittekonsekventne, seevastu eesti rahvalauludes on see aja kestel kujunenud pea- 
miseks loomepõhimõtteks. Sõna otsib justkui parema kokkukõla nimel teist sõna, sel viisil luuakse tähendus, kujund, kirjeldus, võrdlus.

Eesti vanematel rahvalauludel ei ole läti rahvalauludele omast lakoonilisust, need on tihtipeale sajarealised ja pikemadki, seepärast pididki ammused esitajad kasutama keele kõlalisust: assonantse, alliteratsioone, epifoore, refrääne, kordusi jne, mis olid ühtaegu omalaadsed rütmiloomeelemendid. Sõnade kokkukõla nimel ohverdati tihtipeale mõtteloogika; paljude sõnaühendite esialgne tähendus on kadunud või muutunud, ent kõlaline sobivus on jäänud päranduseks otsekui ornament. Sõnatähenduste kokkukõla uurimine on justkui omamoodi keelearheoloogia - see nõuab vanade vormide tundmist. Olen eesti folkloristidelt pärinud, mida tähendab eesti vana rahvalaulu pealkiri „Riia rikkumine”. Enamjaolt arvatakse, et Riia hävitamisega pole sel pealkirjal mingit seost, tegemist on lihtsalt heakõlaga - see on eesti rahvalaulu poeetikast tulenev näide, kus alliteratsiooniga loodi nimetatud sõnaühend. Eesti rahvalauludes võib hulganisti leida taolisi tähendusloogika ja heakõla vahelisi mittevastavusi. See on regilauludes sünnitanud ülikummalisi paradokse, omalaadseid modernisme, näiteks Sibulasta tegin sillad või Ma laulan mere maaks jt.

Eesti vanema rahvalaulu üheks peamiseks loomepõhimõtteks on sajandite kestel kinnistunud vormelite (kindlaksmääratud sõnakombinatsioonide) kasutamine, mida tuleb ka tõlkimisel järgida. Seejuures ei tohi nimetatud vormeleid tõlkida täht-tähelt, ei tohi ka ühe keele rahvalaulude keele ja poeetika struktuuri asendada teise keele rahvalauludele omaste vormelitega. Sutsu vabama läti rahvalaulu traditsioonide interpreteerimisega olen loonud eesti rahvalaulu vormelite lätikeelsed vasted, nõndaviisi sünnib ettekujutus vastavast süsteemist. (Godiṇš 2002: 7)

Läti rahvaluule vorm meenutab haiku struktuuri. Läti rahvalaul on neljarealine, keskel on tsesuur. Paus ei tohi kunagi poolitada sõna. Nii on kujunenud stilistika, kus sõna nagu iseenesest lülitub rütmisüsteemi. Sel moel tekib otsekui rahvalaulu vertikaalne läbilõige.

Kõigi rahvaste laulud tunnevad võrdlust, tegemist on õigupoolest inimest ning ümbritsevat maailma iseloomustava parallelismiga. Läti rahvalaul on lakooniliselt lüüriline, reflektiivselt aforistlik, temas puudub väljaarendatud süžee. Üheks läti rahvalaulu eritunnuseks on arhailisus. (Skujenieks 2003: 407-409)

Eesti vanema rahvalaulu spetsiifikast, poeetikast ja keelest lähtudes olengi üritanud läti rahvalaule eesti keelde ümber panna.

Kas to teica, kas redzēja,

Kā jūrā(i) miežus sēja.

Tad jūrā(i) miežus sēja,

Kad saulite meita bija.

Pūti, pūti, vēja māte, Met jel mieru vakarā.

Dažas labas dvēselītes

Uz ūdeṇa līgojās.
Kesse ütles, kesse nägi,

Otra merre külvatie.

Otra merre külvatie,

Siis kui päike neiu oli.

Puhu, puhu, Tuule ema,

Ole vakka õhtu eeli.

Head, hellad hingekesed

Üle vee veel liikumas. 
Labāk dziedu, nekā raudu,

Lai raud mana launa diena.

Dod, Dievini, vieglu mūžu

Ar dziesmininu nodzīvot!

Igauniski strazdin̄š dzied

Liela ceḷa malin̄ā;

Es gribēju mācīties

Igauniski runāties.
Parem laulan, kui ma nutan,

Nutku minu kuri päev.

Anna, Jumal, kerget elu

Lauldes mulle elada.

Eesti keeles laulab kuldnokk,

Maantee ääres valjusti.

Tahan ise õppida

Eesti keeles rääkima.

\section{„Kalevipoja” tõlkimise spetsiifika}

2018. aasta novembris ilmus minu tõlkes „Kalevipoja” lätikeelne uusversioon (Godiṇš 2018) - mahukas ja väga raske töö. Elīna Zālīte tõlkes 1929. aastal ilmunud „Kalevipoja” lätikeelne tõlge on paljuski vananenud, mittetäielik, vigaderohke. Zālìte tõlkis ilmselt enamjaolt saksa keelest, sestap pole järgitud eesti vanema rahvalaulu poeetilist eripära, samuti pole 1929. aasta väljaandes kommentaare ega muud vajalikku informatsiooni.

„Kalevipoja” lätikeelne uustõlge ilmus kommentaaridega; kui eepose autor F. R. Kreutzwald on kasutanud autentset vanemat eesti rahvalaulu või selle fragmente, siis olen kommentaariumisse lisanud konkreetse rahvalaulu täieliku lätikeelse tõlke. Tänu Eesti Kirjandusmuuseumile olen kogunud väga palju informatiivset materjali eepose loomispõhimõtete, erinevate redaktsioonide, eesti mütoloogia, rahvalaulu poeetika ja keele kohta.

„Kalevipoega” tõlkides olen rangelt järginud rütmi, et tohutut tekstimassiivi oleks võimalik korrastada, et seda oleks hõlpsam lugeda, et kogu teost oleks võimalik tajuda terviklikuna. Algtekstis on väga paljudes kohtades taganetud konsekventsest rütmikast, sest eesti vanema rahvalaulu skandeerimisel (retsiteerimisel) sobitatakse sõna rütmilise raamistikuga, seejuures muudetakse loogilisi rõhke, esineb isegi silpide lisamist. Räägitud/skandeeritud/loetud tekst muutub nõndaviisi ülimalt rütmiliseks. Nagu autentsegi rahvalaulu tõlkimisel, olen ka eepose lätindamisel pööranud suurt tähelepanu heakõlale. Nii olen kasutanud mitmeid vahendeid, et lätikeelne tekst annaks selgelt edasi eesti rahvalaulule omast põhimõtet - keele musikaalsust. Mõned näited:

Lehvi muiste mälestusi,

Kalevide kuulutusi

Kalmu künkast kerkimaie,

Udu-aurust paisumaie,

Hämarikust ärkamaie,

Kanarpikust kasvamaie,

Samblasoosta suitsemaie!

Kussa varjud vaikusela,

Pikad piinad peitusela,

Kurnatused kaane alla

Põrmu põues põonnutavad,
Plandiet, senie stāstījumi, Kaleviešu klāstījumi, Kapu kalnā pakāpdamies, Miklā miglā miglodamies, Sirmā stundā atmozdamies, Viršiem pāri paaugdamies, Sūnu dūnās dūmodamies! Tur, kur slapstās senas ēnas, Slēpjas raizes, bēdu ēdas, Zemzemē zem smaga vāka Gurdi gulšnā plikos pīšḷ̆os, 
Uku hõlmas uinutavad, Maarja rüpessa magavad. (Kreutzwald 1857: 4)

Tuule tuhing tuiskas vile

Laane ladvil laulemaie,

Piki puida puhumaie,

Mööda metsi mõuramaie;

Sundis suvel sõudevaida

Lehekesi lehvimaie,

Käskis kaske kahiseda,

Haava lehti argelikult

Varga küüsil vabiseda,

Röövli kohkel kabiseda.

(Kreutzwald 1857: 6-8)
Uku azotē snauž saldi,

Māras klēpī liekas miegā.

(Godiñ̌š 2018: 19)

Brāzmas brāžas svilpodamas,

Biezā biežñā dziedādamas,

Lielos kokus lauzīdamas,

Meža malā maurodamas;

Vasarās tām zarus cilāt,

Lapām liegi pretī pamāt,

Bērzam braši šalkt un šalkot,

Baigās bailēs apsēm drebēt,

Zag̣̣a nagos trīsās trīsēt.

Laupītāja plestās ketnās.

(Godinš 2018: 19)

\section{„Kalevipoja” keel}

„Kalevipoja” tõlkimisel oli tükk tegemist Kreutzwaldi keelega. Mõned eesti folkloristid ja kirjandusteadlased on rõhutanud, et eepos on kirjutatud kehvas, vananenud, suisa sandistatud eesti keeles. Teised on olnud hoopiski teisel arvamusel ning on ülihoolikalt analüüsinud iga Kreutzwaldi loodud sõna. XIX sajandi esimese poole eesti keel, eriti kirjakeel, elas üle suuri muutusi. (Peegel 1961: 453-454) „Kalevipoeg” pandi kirja sel ajal, mil noorlätlane Juris Alunāns (1832-1864) polnud veel lagedale tulnud oma lennuka ütlemisega: „Neid rahvalaule tõlkides mõtlesin nõndaviisi: tahtsin näidata läti keele jõulisust ja toredust..." Nii ütles see luuletaja ja tõlkija oma 1856. aastal ilmunud raamatu „Dziesmiņas, latviešu valodai pārtulkotas” (e k „Laulukesed, läti keelde tõlgitud") eessõnas - kuid eestlaste kui rahvuse enesetõestuse soov ja eneseteadvuse kasv edestas lätlasi.

„Kalevipoja” lätindamisel olen juhindunud Kreutzwaldist: 1) nimisõnadest olen moodustanud tegusõnu: näiteks dūre - dūrēt ('rusikas' > rusikaga lööma), taka - takot ('rada' > rada mööda kõndima), velve - velvèt ('(katuse) kumm' > kummi tegema); 2) nagu Kreutzwaldki, olen palju kasutanud vanu kesksõnavorme (-dams, -dama, -damies, -damās); 3) teksti kõlaefekti saavutamiseks olen konkreetseid sõnu asendanud sünonüümidega: murdesõnade, regionalismide, arhaismide või rahvakeelsete sõnadega, mis näisid kõlaliselt sobivamana ning olid ühtaegu samatähenduslikud.

Sõnu kombineerides kasutasin tihti kontekstist tulenevat loogikat ja kujundlikkust (assotsiatiivne põhimõte). Eeposes on mitu korda mainitud: Soome tuuslar, tuuletarka. Otsisin sõnale tuuslar sobivat lätikeelset vastet, kasutasin sõna regionalismi bāslis, mis tähendab sama mis burvis ('nõid', 'tuuslar'), kuid esineb harva. Eepose süžee kohaselt röövib tuuslar pettusega Kalevipoja ema, leseks jäänud Linda. Eestikeelse sõna tuuletark ('vēja gudrais') asendasin sõnaga tuisupea ('vējagrābslis'), saades tähenduslikult täpsema, ent algtekstiga samavõrd heakõlalise värsirea - Somu bāslis, vējagrābslis (Soome tuuslar, tuuletarka). 


\section{Uuemate luuletajate luule tõlkimine}

Võin öelda, et Artur Alliksaar on üks minu lemmikluuletajatest. Tema luuletuste läti keelde tõlkimiseks läks vaja põhjalikku arusaamist eesti keele instrumenteerimisvõtetest ja Alliksaare-aegse luuletaja hingelisest ilmatunnetusest, lisaks konkreetseid faktiteadmisi. Kõik minu tõlkeraamatud on olnud mulle otsekui järjekordseks ülikooliks, sest iga kord olen pidanud mitte ainult värsiridu tõlkima, vaid ka uurima ja puurima, et leida lõppude lõpuks neid õigeid sõnu õiges järjekorras: et mitte lõhkuda algallika originaalset kõlapilti, rütmi ja et leida õige viis, kuidas panna neid „minu keelde” - just „minu keele" vahendeid ja võimalusi kasutades. Võiks ju arvata, et Alliksaare luuletusi pole võimalik tõlkida, kuid sel juhul jääksid need läti lugejatel avastamata. Alliksaare lätikeelse tõlkevalimikuga on seotud üks minu kõige meeldivaimaid mälestusi. Istusin ühes Tartu kohvikus, kui mulle astus ligi üks inimene ning kostis, et keegi lätlane luges talle läti keeles ette tema isa Artur Alliksaare luuletusi minu tõlkes. Jaa, see kohvikus kohatud inimene oli Artur Alliksaare poeg ning tema sõnad olid mulle kõige kõrgemaks tunnustuseks.

Olen tõlkinud kaks Alliksaare luulevalimikku. Eelnevalt olin tõlkinud palju soome ja eesti vanu rahvalaule, seepärast suutsin läti lugejatele avada mitte ainult Alliksaare paradoksaalse mõttemaailma, vaid ka tema luuletuste spetsiifika - ikka tollesama keele musikaalsuse. Nii kõlab Artur Alliksaare luule läti keeles:

*

Mõnikord tuled sa tasa nagu tuul ja kuulad mu kummaliste laulude kuminat.

Sind veetleb mu juttude jumi.

Ma ei tea, milline esiema esitas neid esmakordselt mu hälli ees.

Üheski ees ei ole ainult vilja, vaid ka lilli.

Teinekord toob su hooga voogav tooga väärikalt välja mu rõõmude ääred.

Siis sa tunnetad mu läheduse tähendust. [---] (Alliksaar 1997: 354)

*

Dažreiz tu atnāc klusi kā vējš un klausies manu dīvaino dziesmu dimdu.

Tevi valdzina manas runas duna.

Es nezinu, kāda vecāmāte man tās pirmoreiz dziedājusi pie šūpuḷa.

Visam ir ne tikai augli, bet arī ziedi.

Citreiz tu parādies plānas drānas togā no tāliem tālumiem manu prieku krastā.

Tad tu jūti mana tuvuma guvumu. [---]

(Godiñ 2013a: 78)

\section{Tualettide kontsert}

Täna toimub kolossaalne kontsert.

Osavõtjaid on mitusada korda rohkem kui osi, mida võtta.

Algus ei välta enam kui hetke.

Avatakt on tava-akt.

Järgneb järk-järgult jäsenev närvide pinge. 
See pole aga põrmugi ohtlik, sest ansambel sarnaneb ambulatooriumiga.

Klaveri kurgukatarr ei keela keda kõnelemast.

(Tal on palju keeli.)

Tromboonil on tromboos, aga ta ei tee sellest eraldi numbrit ja jätkab jooksu teistega koos.

Oboe on omaks võtnud omapärase kiunumise moe.

Okariin on nagu okassiga ja teda kuulata on päris piin.

Metsasarv on unustanud, et ta pole metsas, ja kisendab kõigest kõrist.

Fagott on fagotsüütidest auklikuks näritud.

Flöödil on lööved, mis eritavad kahtlast fluidumit. [---]

(Alliksaar 1997: 310)

\section{Tualešu koncerts}

Šodien notiks kolosāls koncerts.

Dalībnieku ir simtiem reižu vairāk nekā daḷu, ko dalīt.

Sākums sāksies jau pēc īsa brīža.

Pirmā takts ir prīmā akts.

Šurpu turpu rukā trakā nervu spriedze.

Tā nemaz īsti nav bīstama, jo ansamblis līdzinās ambulancei.

Klavieru kakla katars kāri klāsta savu stāstu.

(Klavierēm ir pulka dzēlīgu mēḷ.)

Trombonam ir tromboze, bet tas nemaz nesatraucas un turpina traukties kopā ar citiem.

Oboja kā orators operē ar spilgtiem smilkstiem.

Okarīna ir kā dzēlīga dzeloṇcūka, tās klausīšanās ir rūgta un grūta.

Mežrags ir aizmirsis, ka nav mežā un kliedz klaigā kaklā.

Fagots no fagocìtiem ir caurumu caurumos.

Flautai ir izsitušies izsitumi, kas izdala šaubīgus fluīdus. [---]

(Godiṇš 2013a: 88)

Ilmar Laabani luuletuste lätindamisel õnnestus mul veel enne autori surma temaga kirjavahetust pidada. Ta oli väga rõõmus, et olen ette võtnud tema luuletuste läti keelde tõlkimise, sest see oli tema emakeel - Laabani ema oli ju lätlanna, ja Ilmar oli vaid 13-aastane, kui ema suri... Mul on tänini alles Laabani kirjad, kus ta andis mulle nõu ja selgitusi oma luuletuste läti keelde tõlkimiseks. Rõõmu teeb seegi, et läti keelde tõlgitud Laabani luulevalimik on ka Läti noore põlvkonna luuletajaid mõjutanud.

Palju luuletusi olen tõlkinud tema raamatust „Ankruketi lõpp on laulu algus”, aga olen tõlkinud ka luuletusi ja aforisme tema omapärasest raamatust „Rroosi Selaviste” (läti nimekuju Rroza Selaviste), mis ilmus 1957. aastal Stockholmis.

*

Rroosi Selaviste on iseenda nimekaim nimekaim.

Rroza Selaviste ir pati savas vārdamāsas vārdamāsa. 
Aga mamma, miks magma ei lähe magama?

Bet mammu, kam gan magma gulēt nemanās?

Rroosi Selaviste jahvatab kirju käsikiviga oma käsikirju.

Rroza Selaviste ar rokas dzirnām mal rakstā savu rokrakstu.

Stiilne nafta on enam kui fantastiline.

Stilistiska nafta ir vairāk nekā fantastiska.

*

Kõik roomad roomavad Rooma.

Visi romieši romā uz Romu.

*

Okkaist ja kokaiinist küpsetab kokk Kain kokku oma koogi.

Koku un kokaīnu pavārs Kains lūko visu kopā klāt savā kūkā.

*

Gorillade koor laulab loori taga „Gloriat”.

Gorillu koris aiz gardīnes gaudo „Gloriju”.

Kümnehambuline dekadent.

Desmitzobains dekadents.

(Laaban 2004: 156-170 / Godiñ 2013b: 72-75)

Olen läti keelde tõlkinud mitte ainult neid eesti luuletajate teoseid, mida iseloomustab peaasjalikult nn keele musikaalsus, vaid ka nn klassikalises luulekeeles kirjutatud luuletusi. Kuulake, kuidas kõlavad läti keeles Juhan Liivi värsid:

\section{Lauliku talveüksildus}

Lumi tuiskab, mina laulan, laulan kurba laulukest, lumi keerleb tuulehoodest, minu süda valudest.

Lumi tuiskab, mina laulan, laulan kurba laulukest; lumi kogub aia ääre, valu minu südame.

Lumi tuiskab, mina laulan, laulan kurba laulukest, laulan, kuni hauas kaetud olen jääst ja lumedest.

(Liiv 1969: 50)

\section{Dziesminieka ziemas vientulība}

Sniegi sijā, un es dziedu, dziedu skumju dziesmu es, sniegi virpuḷo no vēja, sāpes nāk no pasaules.

Sniegi sijā, un es dziedu, dziedu skumju dziesmu es, sniegi krāsies tālā malā, sirds ar sāpēm pierietēs.

Sniegi sijā, un es dziedu, dziedu skumju dziesmu es, kamēr vēji manam kapam pāri ledu, sniegu nes. 


\section{Sa tulid nagu päikene}

Sa tulid nagu päikene kui hommik tulid sa, sa tulid nagu päikene ja ilm lõi särama.

Sa tulid nagu päikene ja paistsid südame, ja kadusid kui päikene öö musta hõlmasse!

(Liiv 1969: 69)

\section{Tu nāci tā kā saulīte}

Tu nāci tā kā saulīte tu atnāci kā rīts, tu nāci tā kā saulīte viss apkārt gaismas tīts.

Tu nāci tā kā saulīte, man spīdēt dvēselē, tu pazudi kā saulīte nakts melnā azotē.

Mainisin, et Jaan Kaplinski oli esimene eesti luuletaja, kelle luuletusi läti keelde tõlkisin. Läti keeles on ilmunud kaks mahukat Kaplinski luulevalimikku. Kaplinski on kirjutanud palju luuletusi vabavärsis, ent on ka üsna palju range kõla- ja rütmivormiga kirjutatud luulet. Üks näide:

$*$

Vaikivad maa ja marjad

leib suhkur ja sool

vaikijaid on palju

ikka igal pool

vaikivad pilved valged

taevasinagi

oota küllap varsti

vaikid sinagi

(Kaplinski 1984: 43)
Klusē zeme un ogas

maize cukurs un sāls

klusētāji ir daudzi

visur klusums tāls

klusē mākoṇi baltie

zilās debesīs

gaidi gan klusēsi

pats tu arī drīz

(Godin̄̌s 2014: 309)

Sama kehtib ka Hando Runneli luule kohta. Nii kõlab läti keeles tema tuntud luuletus „Punaste õhtute purpur”:

PUNASTE ÕHTUTE PURPUR, siniste lootuste lõng, kuulduks kui tasane kur-kur, hõljuks kui imiku hõng, magaja kurgu kur-kur, hinge isekas hõng, pulsi pimestav purpur, lootuste lõputa lõng. (Runnel 2008: 80)

\author{
SARKANO VAKARU PURPURS, \\ zilais cerību diegs, \\ klusi ieskanas kur-kur, \\ trausls kā zīdain \\ krācot rīklē skan kur-kur, \\ elpo dvēseles prieks, \\ asins žilbinošs purpurs, \\ bezgalīgs cerību diegs. \\ (Godin̄š 1998: 91)
}

Siinkohal pole võimalik põhjalikumalt käsitleda eesti lasteluule tõlkespetsiifikat. Läti keeles avaldatud Leelo Tungla lasteluulevalimik „Daudzpusīgais ronis” („Mitmekülgne hüljes”, 2012) pälvis kena vastukaja nii lugejatelt kui ka kriitikutelt. Üks Leelo Tungla luuletus: 


\section{Lätikeelne jäätis}

Sulab lätikeelne jäätis kergelt keele peal: karlumps! Lätikeelne jäätis - näed siis! kõlab uhkelt: saldejums!

Ära jäätisega liiga tee, kui sul on gripp või mumps! Oled terve - sõida Riiga, hüüa uljalt: „Saldejums!”

Võlusõna kaunilt kõlab näiteks „liirum-laarum-lumps!” Läti laste võlusõnad need on „Karums! Saldejums!” (Tungal 2006: 85)

\section{Latviešu valodas saldējums}

Viegli mēlei pieskaroties, ātri kārums izkūst mums! Latvieši ir lepni toties, tiem ir vārdiṇš: saldējums!

Kakls savelkas kā stīga, angīna vai gripa: bums! Esi vesels - brauc uz Rīgu, braši saki: „Saldējums!”

Mums ir skaistu vārdu pāri „līrum-lārum, tīrum-lums!" Latviešiem ir burvju vārdi tie ir: „Kārums!”, „Saldējums!” (Godiṇš 2012: 67)

Hoopis teised reeglid kehtivad Contra, (:)kivisildniku, Veiko Märka irooniliste luuletuste tõlkimisel. Siin on oluline läti keelest üles leida vastavad sõnamängud ja ütlemised. Näiteks üks Contra luuletus:

\author{
$* * *$ \\ hulludel päevadelt \\ ei ostnud midagi \\ lihtsalt hea oli tunda \\ higiseid kehasid \\ tomatipastas \\ enese vastas
}

(Contra 2012: 137)

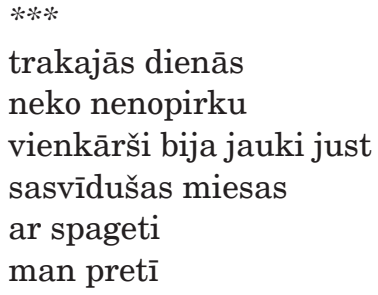

(Godin̦š 2009: 63)

Contral on tomatipastas / enese vastas, mina asendasin läti keelde tõlkides tomatipasta spagetiga: ar spageti / man pretī ('spagetiga / enese vastas').

Ameerika luuletaja Robert Frost on öelnud: „Poetry is what gets lost in translation” („Luule on see, mis tõlkes kaotsi läheb”). Oma pikaajalise kogemuse pealt olen aru saanud, et luuletõlkija peab end keeles vabana tundma, ta peab olema loov, mitte mingil juhul algtekstist hüpnotiseeritud. Ainult siis on võimalik säilitada kõige olulisemat - luule tähenduslikku ja vormilist ühtsust, heakõlalisust jne.

Lõpetan ühe luuletusega, mille kirjutasin aastate eest eesti keeles ja mis käsitleb samuti tõlkimist:

****

Suits on kurb.

Ons suits tule kurbus?

Mille järgi igatseb tuli?

Mis tuli on? 
Tõlgin tuld läti keelde.

Mul kodus on hea

tuha-läti

ja suitsu õigekeelsussõnaraamat.

(Godin̄š 2000: 55)

\section{Kirjandus}

Alliks a a r, Artur 1997. Päikesepillaja. Tartu: Ilmamaa.

Contra 2012. Urvaplaaster. Tallinn: Ilmapress.

Eesti rahvalaulud I. Antoloogia. Toim Ülo Tedre. Tallinn: Eesti Raamat, 1969.

Go d i ñ š, Guntars 1985. Tas nepasacìtais. Rīga: Liesma.

Go d i ṇ š, Guntars (tlk) 1993. Kanteletara. Somu tautas senās dziesmas un balādes. Eliass Lēnrots. Rīga: Nordik.

Go d i n̦ š, Guntars (koost ja tlk) 1998. Hando Runnels. Sarkano vakaru purpurs. Rīga: Minerva.

Go d i n, š, Guntars 2000. Öö päike. Tallinn: Huma.

Go d i n, š, Guntars (koost ja tlk) 2002. Igauṇu tautasdziesmas. Ozols auga debesīs. Rìga: Nordik.

Go d i ṇ š, Guntars (koost ja tlk) 2009. Contra. Kaunis gorjačij igaunis. Rīga: Jāṇa Rozes apgāds.

Go d i n, š, Guntars (koost ja tlk) 2012. Lēlo Tungala. Daudzpusīgais ronis. Rīga: Liels un mazs.

Go d i ṇ š, Guntars (koost ja tlk) 2013a. Arturs Alliksārs. Dzeja. Rīga: Mansards.

Go d i ṇ š, Guntars (koost ja tlk) 2013b. Ilmars Lābans. Putnu mistiskais mugurkauls. Rīga : Neputns.

Go d i ṇ š, Guntars (koost ja tlk) 2014. Jāns Kaplinskis. Balts papīrs un laiks. Rīga: Mansards.

Go diṇ̌š, Guntars (tlk) 2018. Frīdrihs Reinholds Kreicvalds. Kalevdēls. Igauṇu tautas eposs. Rīga: Neputns.

Ka plinski, Jaan 1984. Tule tagasi helmemänd. Tallinn: Eesti Raamat.

[Kreutzwald, Friedrich Reinhold] 1857. Kalewipoeg. Eine Estnische Sage. Verdeutscht von Carl Reinthal. Verhandlungen der gelehrten Estnischen Gesellschaft zu Dorpat. Vierter Band, Erstes Heft. Dorpat: Heinrich Laakmann. http:// krzwlive.kirmus.ee/et/kalevipoeg/tekstiversioon?book_id=16 (23. I 2019).

L a a b a n, Ilmar 2004. Sõnade sülemid, sülemite süsteemid. Koost Jaan Malin ja Ain Kaalep. Tartu: Ilmamaa.

L a u g s te, Eduard 1977. Eesti rahvaluule. Tallinn: Valgus.

Li iv, Juhan 1969. Väike luuleraamat. Koost August Sang. Tallinn: Eesti Raamat.

Pe e gel, Juhan 1961. Lingvistiline pilk „Kalevipojale”. - Keel ja Kirjandus, nr 8, lk 453-457.

Pe e g el, Juhan 1982-1989. Nimisõna poeetilised sünonüümid eesti regivärssides.

1.-4. Tallinn: Eesti Raamat.

Põld mä e, Jaak 1978. Eesti värsiõpetus. Tallinn: Eesti Raamat.

Runn el, Hando 2008 [1982]. Punaste õhtute purpur. Tartu: Ilmamaa.

Skujenieks, Knuts 2003. Daži ceḷrāži latviešu tautasdziesmu ceḷos. Raksti. Rīga: Nordik. 
Tung a l, Leelo 2006. Lätikeelne jäätis ja teisi luuletusi. Tallinn: Tuum.

Zālīte, Elīna (tlk) 1929. Kalevipoegs. Igaunu tautas eps. Frīdrihs Reinholds

Kreicvalds. Rīga: Izglītības ministrijas izdevums.

Guntars Godin̦š (snd 1958), luuletaja ja tõlkija, guntars.godins@inbox.lv

\section{My specifics of translating Estonian poetry}

Keywords: translation, poetry, Estonian literature, Estonian, Latvian

The author shares his experience, spanning close to forty years, translating Estonian and Finnish poetry. In the process of translating, he has gained knowledge and developed his own system for dealing with ancient Estonian folksongs, the epic poem Kalevipoeg, as well as the poems by such authors as Ilmar Laaban, Artur Alliksaar, Andres Ehin, Juhan Liiv, Hando Runnel, Jaan Kaplinski, Hasso Krull and others.

The highlights of the paper are as follows: the specifics of Estonian as compared to Latvian; the common and the distinctive (lack of grammatical gender and future, musical qualities of Estonian etc.); the specifics of the form and poetics of the old Estonian folksong (regivärss), representing the form, metrics, sound (alliteration, assonance) of Estonian in Latvian; the specifics of translating Kalevipoeg, its most important differences compared to the ancient Estonian folksongs (coining new word forms and words, translating the special language of Friedrich Reinhold Kreutzwald into modern Latvian); the peculiarities of Ilmar Laaban's poetics and wordplays in his book of surrealist poetry Rroosi Selaviste as translated into Latvian; expressing the musical nature, thought and feeling in Artur Alliksaar's poetic language; translating the classical Estonian poems (metre, rhythm, rhymes, intonation) by Juhan Liiv, Hando Runnel, Jaan Kaplinski and others; the possibilities and principles of translating the wordplays of Contra, (:)kivisildnik, Veiko Märka and others.

The author brings many examples from Estonian and Latvian to illustrate his conclusions. The author emphasizes that in addition to representing the form, rhythmical structure and intonation, equally important is the ability of the translator to improvise, to feel free in his/her language and poetics, for this is the only way to lose less in translation.

Guntars Godin̦š (b. 1958), poet and translator, guntars.godins@inbox.lv 